\title{
Enhancing Cabbage (Brassica oleraceae Var capitata) Yields and Quality Through Microclimate Modification and Physiological Improvement Using Agronet Covers
}

\author{
Everlyne M. Muleke ${ }^{1}$, Mwanarusi Saidi ${ }^{1}$, Francis M. Itulya ${ }^{1}$, Thibaud Martin ${ }^{2,3}$ \& Mathieu Ngouajio ${ }^{4}$ \\ ${ }^{1}$ Egerton University, Department of Crops, Horticulture and Soils, P.O Box 536 - 20115, Egerton - Kenya \\ ${ }^{2}$ CIRAD UR Hortsys, Avenue Agropolis, 34398 Montpellier Cedex 5, France \\ ${ }^{3}$ Icipe, Plant health Department, P.O Box 30772-00100, Nairobi, Kenya \\ ${ }^{4}$ Mathieu Ngouajio, Department of Horticulture, Michigan State University, USA \\ Correspondence: Mathieu Ngouajio, Department of Horticulture, Michigan State University, 1066 Bogue Street, \\ Plant and Soil Science Building, East Lansing, MI 48824, current address National Institute of Food and \\ Agriculture (NIFA) Washington DC. Tel: 1-202-401-4895; Fax: 1-202-401-6488. E-mail: \\ mngouajio@nifa.usda.gov
}

Received: December 29, $2013 \quad$ Accepted: February 12, $2014 \quad$ Online Published: February 17, 2014
$\begin{aligned} & \text { doi:10.5539/sar.v3n2p24 } \\ & \text { URL: http://dx.doi.org/10.5539/sar.v3n2p24 }\end{aligned}$

\begin{abstract}
Adverse environmental conditions have contributed to perpetual poor cabbage (Brassica oleraceae var. capitata) yields in sub-Saharan Africa. Elsewhere, net covers have been reported to provide a low-cost technology with the potential of modifying the microclimate around a crop for better performance. Two experiments were therefore conducted over a span of two seasons to determine the effects of agronet covers on microclimate modification and subsequent cabbage yield and quality. The treatments comprised cabbage plants grown under either fine mesh $(0.4 \mathrm{~mm}$ pore diameter) or large mesh $(0.9 \mathrm{~mm}$ pore diameter $)$ agronet covers maintained permanently closed, or opened thrice weekly from 9 am to $3 \mathrm{pm}$ and a control treatment where cabbage was grown in the open field. Net covering generally modified the microclimate by raising temperatures, relative humidity and volumetric water content but lowering photosynthetic active radiation and diurnal temperature range compared to control. The use of agronet covers resulted in better cabbage performance. The large mesh $(0.9 \mathrm{~mm})$ enhanced leaf stomatal conductance and chlorophyll content, and improved fresh and dry weight as well as head quality. Results of this study present the use of agronet covers as a potentially effective technology for use by small-scale farmers in protected cabbage culture in sub-Saharan Africa.
\end{abstract}

Keywords: eco-friendly nets, crop environment, low cost production, cabbage performance, protected cropping

\section{Introduction}

Cabbage (Brassica oleraceae var. capitata) is an important vegetable mainly grown by resource restrained smallholder farmers for food. It is estimated that nearly half a million families in the countrysides of Africa derive substantial on-farm earning through the cultivation of cabbage (FAO, 2009). In Kenya for example, farming and marketing of cabbage provides a secure source of continuous income and enables small farms to remain financially viable, especially in the rapid growing peri-urban farming sector (Wambani et al., 2007). Despite the important role of cabbage, average yields per unit area of the crop is estimated at 15 tons $^{-1}$ in Kenya (HCDA Report, 2008) and 30 tons $^{-1} \mathrm{i}^{-1}$ sub-Saharan Africa (Allemann \& Young, 2008), figures that fall far below the worldwide average production of 50 tons $\mathrm{ha}^{-1}$.

Adverse ecological conditions including constant fluctuations in temperature, relative humidity, soil moisture and light factors have been cited among the major constraints to optimal cabbage production in many parts of Africa (Levasseur et al., 2006). Cabbage is a cool season crop with moderately low optimum temperatures of 15 to $20{ }^{\circ} \mathrm{C}$ and high water requirement for optimum performance. Cabbage growth, heading and consequently yields are greatly reduced under higher temperatures. Low moisture due to factors such as low and erratic relative humidity and poor soil moisture retention also adversely affect yields and quality of the crop. In most sub-Saharan countries, however, cabbage is still mostly grown in open fields. This exposes it to supra-optimal 
solar radiation of the tropics, low moisture conditions and thermal fluctuations, which result in poor performance of the crop.

Netting technology has been used to protect crops from excessive solar radiation and other environmental hazards in the developed countries, with better microclimate conditions for crop growth recorded under the net covers compared to open field environment (Majumdar, 2010). Net covers have also been documented to have a potential for providing an amicable solution to sustainable and affordable cabbage transplant and/or crop production in sub-Saharan Africa (Muleke et al., 2013). This study aimed at establishing the effects of using agronet covers on the immediate microclimate of a cabbage crop and how this affects the physiological performance and yield of the crop.

\section{Method}

\subsection{Site Description}

The study was a two-season experiment (May-Aug., 2011 and Oct., 2011-Jan., 2012) conducted at the Horticulture Research and Teaching Field, Egerton University, Kenya. The area lies at altitude $2238 \mathrm{~m}$, latitude $0^{\circ} 23^{\prime} \mathrm{S}$ and longitude $35^{\circ} 35^{\prime} \mathrm{E}$. The average maximum and minimum temperatures range between 19 to $22^{\circ} \mathrm{C}$ and 5 to $8{ }^{\circ} \mathrm{C}$, respectively. The area receives an annual rainfall of 900 to $1200 \mathrm{~mm}$ (Egerton Metrological Station, 2009).

\subsection{Experimental Design and Treatments}

The study used a randomized complete block design (RCBD) with five replications and five treatments. The treatments comprised of growing cabbage in the open as the control treatment or under (i) $0.4 \mathrm{~mm}$ mesh size net maintained permanently covered (ii) $0.9 \mathrm{~mm}$ mesh size net maintained permanently covered (iii) $0.4 \mathrm{~mm}$ mesh size net opened thrice weekly from $9 \mathrm{am}$ to $3 \mathrm{pm}$ or (iv) $0.9 \mathrm{~mm}$ mesh size net opened thrice weekly from 9 am to $3 \mathrm{pm}$. In net-covered plots, wooden plunks were used to make arches to support the nets. The arches were $2 \mathrm{~m}$ wide and $0.3 \mathrm{~m}$ high, after being secured $0.2 \mathrm{~m}$ into the ground. Four such arches were used per plot mounted at $1.5 \mathrm{~m}$ apart along the $6 \mathrm{~m}$ length of the plot. Each of the 5 blocks measured $2 \mathrm{~m}$ by $38.5 \mathrm{~m}$ separated by a $1 \mathrm{~m}$ buffer. Individual plots within a block measured $2 \mathrm{~m}$ by $6 \mathrm{~m}$ separated by $0.5 \mathrm{~m}$ paths. The agronets were manufactured by A to Z Textile Mills, Arusha, Tanzania. They were white in colour and made from high-density polyethylene, which makes them durable with a potential life span of up to 4 years.

\subsection{Plant Material, Planting and Crop Maintenance}

Healthy Gloria F1 hybrid cabbage seedlings produced under agronets were transplanted at a spacing of $40 \mathrm{~cm}$ by $40 \mathrm{~cm}$ giving a total of 75 plants per plot. Triple superphosphate $\left(46 \% \mathrm{P}_{2} \mathrm{O}_{5}\right)$ fertilizer was used at planting at the rate of $225 \mathrm{~kg} \mathrm{ha}^{-1}$. Following transplanting, all the plots received a blanket spray of Bestox $\left(50 \mathrm{~g} \mathrm{l}^{-1}\right.$ alpha-cypermethrin) at the rate of $15 \mathrm{ml}$ per 20 litres of water, against any pests accrued during the transplanting process. This was done just before mounting of agronets on the net covered plots. A calcium ammonium nitrate $(26 \% \mathrm{~N})$ top dress was applied in two equal splits: at three and six weeks after transplanting to all plots at the total rate of $215 \mathrm{~kg} \mathrm{ha}^{-1}$. Thereafter, cabbage crop management practices like watering and weeding were carried out uniformly on need basis on all plots throughout the study.

\subsection{Data Collection}

\subsubsection{Microclimate Data}

WatchDog Plant Growth Station data loggers model 2475 (Spectrum Technologies, Inc. 3600 Thayer Court, Aurora, IL 60504 USA) were used to collect data on air temperature, relative humidity, volumetric soil water content, quantum light (PAR) and diurnal temperature range. The data loggers were each screwed on a wooden post, $10 \mathrm{~cm}$ high at the centre of each treatment. The loggers were programmed to record data hourly, which were then averaged daily. Accumulated data were downloaded on a weekly basis for safety.

\subsubsection{Leaf Chlorophyll Content and Stomatal Conductance}

Leaf chlorophyll content estimates in chlorophyll concentration index (CCI) units were collected using chlorophyll meter (CCM-200 Plus, Opti-Sciences Inc. 8 Winn Avenue Hudson NH 03051 USA). The leaf chlorophyll content estimates were taken from a recently fully expanded leaf of 20 tagged cabbage plants in the inner rows of each treatment. Estimation of chlorophyll was done after every two weeks starting the fifth week after transplanting (WAT). Stomatal conductance was also taken from the same leaf on which chlorophyll content was estimated. This was achieved using a steady state leaf porometer (SC-1, Decagon Devices, Inc. Hopkins Court Pullman, USA). The readings were also taken after every two weeks from 5 WAT and recorded in $\mu \mathrm{mol} \mathrm{m} \mathrm{s}^{-1}$. 


\subsubsection{Yield and Plant Dry Weight}

Upon crop maturity, 20 cabbage plants were selected at random and uprooted from each plot as a representative sample of the crop in the different treatments. The harvested cabbage was used for determination of the total plant fresh weight and fresh head weight. Before weighing, the stems and roots were washed using clean water to remove any adhered soil particles and then wiped dry using a clean cotton cloth. Using a mechanical weighing pan scale (10 kg per $40 \mathrm{~g}, 18636$, Shenzhen west-Boao Science and technology Co. Ltd), the weight of the whole plant was taken and thereafter that of the fresh head alone with both measurements done in kilograms per plot $\left(\mathrm{kg} \mathrm{plot}^{-1}\right)$ and later converted into metric tonnes per hectare $\left(\mathrm{MT} \mathrm{ha}^{-1}\right)$. Thereafter, a random sample of 5 heads was picked from the 20 heads initially harvested from each plot and separately chopped into smaller pieces, thoroughly mixed and put in separate containers. A sample of $100 \mathrm{~g}$ was then drawn from each container, put in paper bags and oven dried at $75^{\circ} \mathrm{C}$ to a constant weight. The dry weight for each $100 \mathrm{~g}$ fresh head weight sample was then determined and used to compute total head biomass using the formula:

$$
\text { Total head weight/plant }=\text { Total fresh weight/ head } * \text { Dry weight/100 g fresh weight }
$$

\subsubsection{Quality Parameters}

Head firmness, total soluble solids and percent moisture content were the quality parameters considered in this study. Cabbage head firmness was determined using the 5 randomly sampled cabbage heads used to determine head dry weight before they were chopped. The head firmness was measured using a hand held penetrometer (model FT327, QA Supplies, LLC. U.S.A), probe no. 16, by exerting pressure on the head. The reading in force $(\mathrm{kg})$ at which the cabbage head was punctured indicated the head firmness. From the remainder of the chopped up cabbage used to determine dry weight, a handful was taken from every treatment for Total soluble solids (TSS) determination. Fluid was squeezed from the tissues by hand and the TSS of the extracted liquid determined using a hand held refractometer (model RHB-32atc, Fuzhou Hedao Trade Co. Ltd. China) and recorded as \% brix TSS. Percent moisture content was determined from the sample of $100 \mathrm{~g}$ that was oven dried at $75^{\circ} \mathrm{C}$ to a constant weight during dry matter determination using the formula:

$$
\text { Percent moisture }=[(100 \mathrm{~g} \text { Fresh weight }- \text { Dry weight }) / 100] * 100
$$

\subsection{Data Analysis}

Data collected was subjected to Analysis of Variance (ANOVA) using PROC GLM code of SAS (version 9, 2005). Means were separated using the Tukey's Honestly Significant Difference Test at $P \leq 0.05$. Since season by treatment interaction was not significant, data for the two seasons were pooled and analysed together using the RCBD model:

$$
Y_{i j k}=\mu+\rho_{i}+\beta_{k}+\varepsilon_{i j l}
$$

where, $\boldsymbol{Y}_{i j k}$ is the cabbage response, $\boldsymbol{\mu}$ is the grand mean, $\boldsymbol{\rho}_{\boldsymbol{i}}$ is the $\mathrm{i}^{\text {th }}$ blocking effect $(\mathrm{i}=1,2,3,4,5), \boldsymbol{\beta}_{\boldsymbol{k}}$ is the $\mathrm{k}^{\text {th }}$ treatment effect $(\mathrm{k}=1,2,3,4,5)$, and $\varepsilon_{i j k}$ is the random error component which are normally and independently distributed about zero means with a common variance $\sigma^{2}$.

\section{Results}

\subsection{Crop Environment}

\subsubsection{Air Temperature}

The use of agronet covers modified the cabbage crop environment with higher temperatures recorded under agronets plots compared to uncovered treatments throughout the study (Figure 1A). Averaged over the two seasons, mean temperatures were $23.4{ }^{\circ} \mathrm{C}$ under $0.4 \mathrm{~mm}$ agronet used permanently, $21.1{ }^{\circ} \mathrm{C}$ under $0.4 \mathrm{~mm}$ agronet opened thrice weekly, $19.1{ }^{\circ} \mathrm{C}$ under $0.9 \mathrm{~mm}$ agronet used permanently; $18.7^{\circ} \mathrm{C}$ under $0.9 \mathrm{~mm}$ agronet opened thrice a week and $17.9^{\circ} \mathrm{C}$ under the control. This corresponded to $5.5{ }^{\circ} \mathrm{C}, 3.2{ }^{\circ} \mathrm{C}, 1.2{ }^{\circ} \mathrm{C}$ and $0.6{ }^{\circ} \mathrm{C}$ increase in temperatures following the use of $0.4 \mathrm{~mm}$ agronet permanently, $0.4 \mathrm{~mm}$ agronet opened thrice a week, $0.9 \mathrm{~mm}$ agronet permanently and $0.9 \mathrm{~mm}$ agronet opened thrice a week, respectively compared to the control treatment.

\subsubsection{Relative Humidity}

Relative humidity $(\mathrm{RH})$ within the immediate crop environment also displayed a trend similar to that of temperature. It was highest under $0.4 \mathrm{~mm}$ netting used permanently and lowest under the control treatment throughout the study (Figure 1B). The mean relative humidity for the two seasons was $84.4 \%$ under the $0.4 \mathrm{~mm}$ netting used permanently and $82.2 \%$ under the same mesh size netting opened thrice a week against $73.6 \%$ relative humidity recorded for the control treatment. This depicted a $10.8 \%$ and $8.6 \%$ increase in relative 
humidity when the $0.4 \mathrm{~mm}$ agronet was used permanently or opened thrice a week, respectively. Relative humidity under the $0.9 \mathrm{~mm}$ agronets was on the other hand, $80.3 \%$ and $77.8 \%$ when used permanently and when opened thrice a week, respectively corresponding to $6.1 \%$ and $4.2 \%$ increase, respectively.

(A)

| $\operatorname{LSD}(\mathrm{p}=0.05)$
(B)

| $\operatorname{LSD}(\mathrm{p}=0.05)$
(C)

$\operatorname{LSD}(p=0.05)$
(D)

| $\operatorname{LSD}(\mathrm{p}=0.05)$
(E) $\operatorname{LSD}(\mathrm{p}=0.05)$
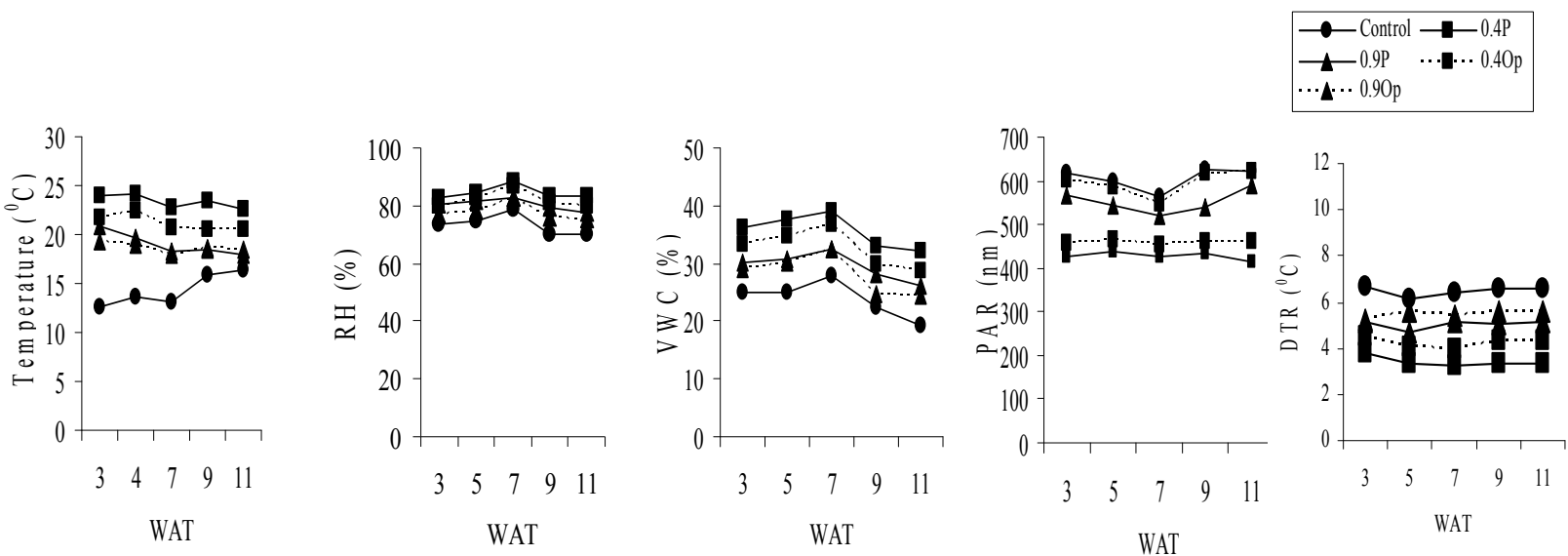

Figure 1. Air temperature (A), Relative humidity (B), Volumetric water content (C), Photosynthetic active radiation

(D) and Diurnal temperature range (E) profiles as influenced by agronet covers during cabbage production

Season 1 (May-Aug, 2011) and season 2 (Oct-Jan, 2012). Control had no agronet cover, Op is where the agronet was opened three times a week, $\mathrm{P}$ is where agronet was maintained permanently covered except during maintenance and data collection periods while 0.4 and 0.9 were the different agronet mesh sizes $(\mathrm{mm})$.

\subsubsection{Volumetric Water Content}

The use of agronet covers also improved the volumetric water content (VWC) of the immediate cabbage soil environment. Using the $0.4 \mathrm{~mm}$ agronet permanently resulted in the highest volumetric water content while the lowest volumetric water content was in soils of uncovered plots at all sampling dates (Figure 1C). The mean volumetric water content for the control treatment during the study period was $23.9 \%$ against $35.6 \%$ under the $0.4 \mathrm{~mm}$ agronet used permanently and $32.7 \%$ under the $0.4 \mathrm{~mm}$ agronet opened thrice a week. The $0.9 \mathrm{~mm}$ agronet net used permanently recorded a VWC of $29.6 \%$, and $28.2 \%$ under the $0.9 \mathrm{~mm}$ agronet net opened thrice weekly accounting for an $11 \%, 8 \%, 5.7 \%$ and $4.3 \%$ increase in soil moisture content following the use of the respective agronet treatments.

\subsection{Photosynthetic Active Radiation}

The use of agronet covers lowered the Photosynthetic active radiation (PAR) received by the cabbage crop. Covered plots consistently recorded lower PAR than uncovered treatments throughout the study period (Figure 1D). Amongst the agronet-covered treatments, PAR was consistently lower under the $0.4 \mathrm{~mm}$ netting treatments compared to under the $0.9 \mathrm{~mm}$ netting. Averaged across the seasons, the mean PAR under the $0.4 \mathrm{~mm}$ net used permanently and opened thrice a week was $427.6 \mathrm{~nm}$ and $460.2 \mathrm{~nm}$, respectively. Meanwhile, the $0.9 \mathrm{~mm}$ used permanently registered a PAR of $552.2 \mathrm{~nm}$ against $595.5 \mathrm{~nm}$ when opened thrice a week. The highest PAR was obtained under the no-net cover control, which registered a mean PAR of $605.4 \mathrm{~nm}$.

\subsection{Diurnal Temperature Range}

Similar to PAR, Diurnal temperature range (DTR) within the vicinity of the crop was lowered with the use of agronet covers. Diurnal temperature range remained high under the uncovered control and lowest under the 0.4 $\mathrm{mm}$ agronet maintained permanently covered in all sampling dates (Figure 1E). Over the study period, the 0.4 $\mathrm{mm}$ mesh agronet registered a mean diurnal temperature range of $3.4{ }^{\circ} \mathrm{C}$ and $4.2{ }^{\circ} \mathrm{C}$ when maintained permanently covered or opened thrice a week, respectively. Mean diurnal temperature ranges were $5.0^{\circ} \mathrm{C}$ under the $0.9 \mathrm{~mm}$ mesh agronet when used permanently and $5.1{ }^{\circ} \mathrm{C}$ when opened thrice a week. The control treatment 
had a mean diurnal temperature of $6.4{ }^{\circ} \mathrm{C}$. This depicted a $3.0^{\circ} \mathrm{C}, 2.2{ }^{\circ} \mathrm{C}, 1.4{ }^{\circ} \mathrm{C}$ and $1.3{ }^{\circ} \mathrm{C}$ decrease in diurnal temperature range with the use of the $0.4 \mathrm{~mm}$ mesh agronet maintained permanently covered or opened thrice a week and the $0.9 \mathrm{~mm}$ mesh agronet used permanently or opened thrice a week, respectively.

\subsection{Leaf Stomatal Conductance and Chlorophyll Content}

The stomatal conductance of cabbage leaves was enhanced by the use of agronet covers. Throughout the study, leaf stomatal conductance was consistently higher in cabbage plants grown under agronets and lowest under the uncovered plants (Figure 2). Cabbage plants under the permanent use of $0.9 \mathrm{~mm}$ netting registered significantly higher stomatal conductance followed by plants under the $0.9 \mathrm{~mm}$ net opened thrice a week. Plants under the 0.4 $\mathrm{mm}$ net used permanently and $0.4 \mathrm{~mm}$ net opened thrice a week, had slightly lower stomatal conductance with control plants exhibiting the lowest stomatal conductance at all sampling dates. Mean stomatal conductance for the study period were $395.8 \mu \mathrm{mol} \mathrm{m} \mathrm{sec}^{-2}, 354.1 \mu \mathrm{mol} \mathrm{m} \mathrm{sec}^{-2}, 328.8 \mu \mathrm{mol} \mathrm{m}^{-1} \mathrm{sec}^{-2}, 317.0 \mu \mathrm{mol} \mathrm{m}^{-1} \mathrm{sec}^{-2}$, and $277.4 \mu \mathrm{mol} \mathrm{m}^{-1} \mathrm{sec}^{-2}$ for the $0.9 \mathrm{~mm}$ netting used permanently, the $0.9 \mathrm{~mm}$ net netting opened thrice a week, the $0.4 \mathrm{~mm}$ net used permanently, the $0.4 \mathrm{~mm}$ net opened thrice a week and the control treatments, respectively. Similarly, cabbage leaf chlorophyll content was also enhanced by growing the crop under agronet covers (Figure 2). With progressive increase crop age, plants grown under $0.9 \mathrm{~mm}$ nets presented significantly $(\mathrm{p}=0.05)$ higher chlorophyll content values than those under $0.4 \mathrm{~mm}$ net and the uncovered control. Averaged over the study period, the chlorophyll content of leaves of $0.9 \mathrm{~mm}$ net covered cabbage was $72.2 \mathrm{CCI}$ when permanently used and $70.1 \mathrm{CCI}$ when opened thrice a week. On the other hand, cabbage grown under the $0.4 \mathrm{~mm}$ net used permanently recorded chlorophyll contents of $56.3 \mathrm{CCI}$ and $64.4 \mathrm{CCI}$ when opened thrice a week. The uncovered plants had significantly lower mean chlorophyll content of 45.6 CCI.
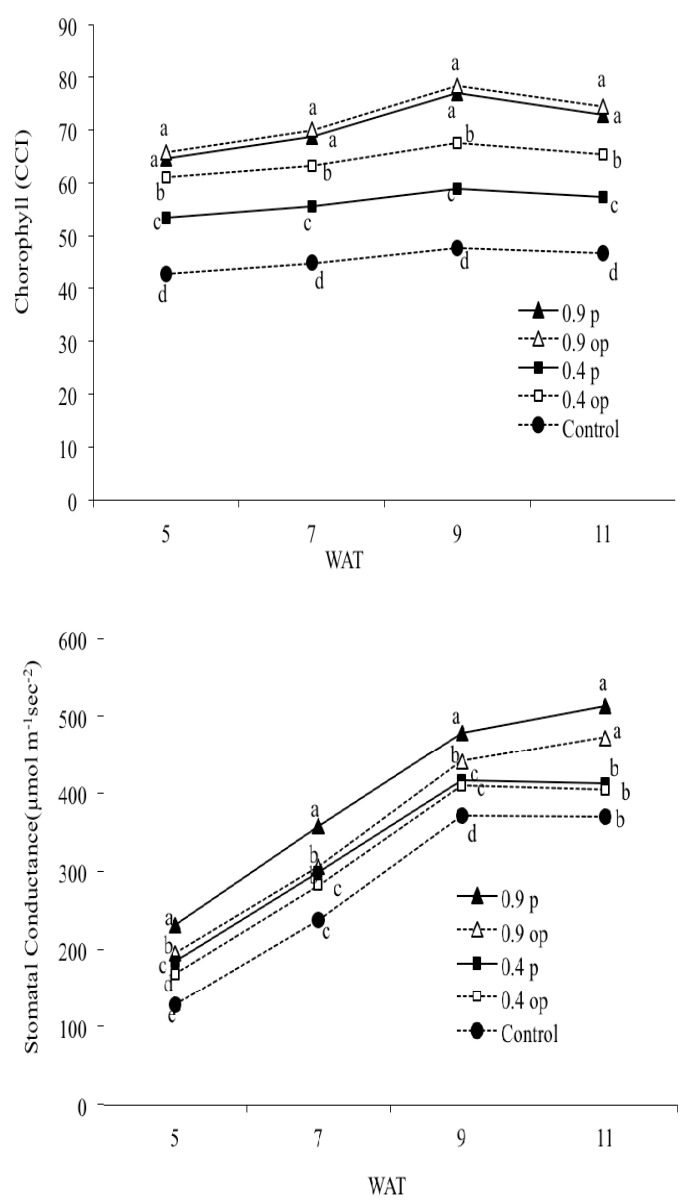

Figure 2. Leaf stomatal conductance and chlorophyll content profiles as influenced by agronets during cabbage experiment in season 1 (May - Aug, 2011) and season 2 (Oct 2011 - Jan, 2012)

Control had no agronet cover; op is where the agronet was opened three times a week, $p$ is where the agronet was maintained permanently covered except during maintenance and data collection periods while 0.4 and 0.9 
$\mathrm{mm}$ were the different agronet mesh sizes. Within each parameter and WAT data points with the same letter are not significantly different according to the Tukey's HSD test $(\mathrm{p} \leq 0.05)$

\subsection{Yields}

Growing cabbage under agronet covers significantly increased head fresh weight (Table 1). The use of the larger mesh size of $0.9 \mathrm{~mm}$ pore diameter agronet cover maintained permanently resulted in the highest yields followed by the same mesh size maintained by opening thrice a week. The lowest yield was obtained from the control treatment. Among the agronet-covered treatments, the yields were lowest under the $0.4 \mathrm{~mm}$ agronet cover maintained permanently. An analysis of the unmarketable yields due to various defects, revealed a trend opposite to that of total yields (Table 1). The highest unmarketable cabbage yield was obtained in the control treatment while the lowest was under the $0.9 \mathrm{~mm}$ permanent cover. Cabbage grown under agronet covers also accumulated more dry matter than that grown in the open field (Table 1). Generally, the use of the larger mesh agronet of 0.9 mm pore diameter yielded cabbage with higher dry matter than the finer $0.4 \mathrm{~mm}$ pore diameter agronet while the least dry matter accumulation was in open field grown cabbage.

Table 1. Cabbage head fresh yield and selected quality attributes as influenced by agronet covers season 1 (May-Aug, 2011) and season 2 (Oct 2011 - Jan, 2012)

\begin{tabular}{cccccc}
\hline Treatment* & $\begin{array}{c}\text { Fresh yield } \\
\text { MT ha }^{-1}\end{array}$ & $\begin{array}{c}\text { Unmarketable yield } \\
\text { MT ha }^{-1}\end{array}$ & $\begin{array}{c}\text { Water content } \\
(\%)\end{array}$ & $\begin{array}{c}\text { TSS } \\
(\%)\end{array}$ & $\begin{array}{c}\text { Firmness } \\
\text { force }(\mathrm{kg})\end{array}$ \\
\hline Control & $101.40^{\mathrm{cd} * *}$ & $33.77^{\mathrm{a}}$ & $85.45^{\mathrm{bc}}$ & $5.90^{\mathrm{a}}$ & $3.9^{\mathrm{c}}$ \\
0.9 mm opened & $176.86^{\mathrm{ab}}$ & $16.5^{\mathrm{c}}$ & $91.08^{\mathrm{abc}}$ & $4.53^{\mathrm{b}}$ & $4.85^{\mathrm{b}}$ \\
$0.9 \mathrm{~mm}$ permanent & $183.06^{\mathrm{a}}$ & $6.21^{\mathrm{d}}$ & $91.92^{\mathrm{ab}}$ & $4.50^{\mathrm{b}}$ & $5.25^{\mathrm{a}}$ \\
0.4 mm opened & $119.25^{\mathrm{c}}$ & $20.36^{\mathrm{b}}$ & $92.0^{\mathrm{ab}}$ & $3.75^{\mathrm{c}}$ & $4.4^{\mathrm{bc}}$ \\
$0.4 \mathrm{~mm}$ permanent & $105.68^{\mathrm{cd}}$ & $19.63^{\mathrm{b}}$ & $92.45^{\mathrm{a}}$ & $3.6^{\mathrm{c}}$ & $4.3^{\mathrm{bc}}$
\end{tabular}

*Control treatment had no agronet cover, opened is where the agronet was opened three times a week, permanent is where the agronet was maintained permanently covered except during maintenance and data collection periods while $0.4 \mathrm{~mm}$ and $0.9 \mathrm{~mm}$ were the different agronet mesh sizes used.

**Values followed by the same letter within a parameter are not significantly different according to the Tukey's HSD test $(\mathrm{p} \leq 0.05)$.

\subsection{Selected Cabbage Quality Attributes}

Growing cabbage under the $0.9 \mathrm{~mm}$ or $0.4 \mathrm{~mm}$ netting resulted in more succulent cabbage as evidenced by the higher water content. Whether maintained as a permanent cover or opened thrice a week, cabbage water content remained significantly high in both nets and lowest in the control (Table 1). Although moisture content was higher for cabbage heads from the finer $0.4 \mathrm{~mm}$ agronet compared to that of cabbage grown under the larger 0.9 $\mathrm{mm}$ agronet, the differences were not significant at $\mathrm{p} \leq 0.05$.

Contrary to moisture content, lower TSS was associated with the use of agronet covers in cabbage production (Table 1). Cabbage grown under the $0.4 \mathrm{~mm}$ agronet treatments recorded the lowest TSS followed by that from the $0.9 \mathrm{~mm}$ agronet covers with the highest TSS being obtained in control cabbage. The use of agronet covers however, yielded firmer cabbage heads than when the crop was grown in the open field (Table 1). The most firm cabbage heads were those grown under the $0.9 \mathrm{~mm}$ permanently covered agronet yield followed by those grown under the same mesh size agronet opened thrice a week. The least firm cabbage heads were obtained from the uncovered control. All $0.4 \mathrm{~mm}$ agronet covers yielded cabbage heads that were firmer than those under open field production but less firm than those under the $0.9 \mathrm{~mm}$ agronets covers.

\section{Discussion}

\subsection{Effects of Agronet Cover on the Crop Environment}

The agronet covers modified all microclimate variables under study. Air temperature, relative humidity and volumetric water content remained higher in agronet covered than in uncovered treatments throughout the study. On the other hand, photosynthetic active radiation and diurnal temperature range were reduced by the use of net covers. For all microclimate variables under study, the extent of modification was also influenced by the size of 
the mesh used and whether the covers were maintained permanently covered or managed by opening them thrice a week. Microclimate modification was generally greater under the finer agronet mesh size of $0.4 \mathrm{~mm}$ than under the larger mesh size of $0.9 \mathrm{~mm}$. A greater microclimate modification was also obtained by maintaining the agronets permanently covered than when they were opened thrice a week for ventilation. The existence of a screen has been shown to alter the exchange of radiation, momentum and mass between the crop and the atmosphere hence modifying the crop microclimate (Lloyd et al., 2005). Screens reduce the mixing of outside air with inside air thus reduce heat loss to the surrounding atmosphere, which leads to a temperature build up (Tanny et al., 2003). The finer mesh $(0.4 \mathrm{~mm})$ used in the current study possibly provided more resistance to air movement than the larger mesh $(0.9 \mathrm{~mm})$ leading to the higher temperatures recorded under the finer agronet than under the larger mesh size net. Findings of this study agree with those of Perez et al. (2006) on leather leaf fern, Tanny et al. (2003) on tomato and Stamps (1994) on cut foliage where netting screen increased temperature by $2.3^{\circ} \mathrm{C}$ to $5^{\circ} \mathrm{C}$.

Relative humidity was also higher under agronets than in the uncovered plots in the current study. Relative humidity is often higher under netting than outside as a result of water vapour being transpired by the crop and reduced mixing of drier air outside with that of the netted area, even when temperatures under the netting are higher than the outside (Elad et al., 2007). Reduction in radiation resulting from netting also contributes to increased relative humidity with finer mesh providing a higher shade factor than larger mesh sizes (Stamps, 1994). Besides reducing radiation, nettings also reduce wind speeds, which in turn minimize mixing of inside air with outside dry air hence maintaining a higher relative humidity (Tanny et al., 2003). These arguments lend support to the observations made in the current study where a higher relative humidity was observed under agronet-covered plots than in the uncovered plots. Among the agronet covered plots, relative humidity was highest under the finer mesh $(0.4 \mathrm{~mm})$ than under the larger mesh $(0.9 \mathrm{~mm})$ possibly due to greater resistance to air movement and mixing offered by the finer mesh compared to the larger mesh agronet covers. These findings are in line with results by Cicero et al. (2012) who recorded a 2 to $6 \%$ increase in relative humidity with the use of different nets.

In the current study, volumetric soil water content was higher under the agronet covers than the uncovered plots. The existence of shade netting may have reduced soil evaporation rate under netted areas due to restricted air movement, resulting in higher soil water retention. According to Akpo et al. (2005) one of the potential benefits of net covers above crops is creation of a shading effect. Such an effect, coupled with high atmospheric water content slows the rate of evaporation and retains higher water content in the soil. Another possible explanation to the higher soil moisture level under covers is the reduction of transpiration thereby minimised water uptake by plants leading to increased moisture retention in the soil (Iglesias \& Alegre, 2006). This attribute of net covers presents a potential for lowering cabbage crop irrigation requirement. Similar to the findings of the current study, Akpo et al. (2005) observed increased volumetric water content in soils under shade than in the open.

Although the amount of light reaching the cabbage crop was in this study reduced under net covers with the highest reduction observed under the fine mesh $(0.4 \mathrm{~mm})$, light reaching the cabbage crop under all the covers still fell within the PAR region. Our observations indicate the possibility of finer mesh size nets filtering more light hence lowering the amount of PAR reaching the crop. In a study by Retamales et al. (2008), white nets reduced photosynthetic active radiation by $28 \%$ when used in high bush berry production. In apples, overall, incident solar radiation (as PAR) was reduced by $12 \%$ with the use of white (crystal, translucent) hail nets relative to the control outside (Solomakhin \& Blanke, 2009). Similar to these findings, PAR reaching the cabbage crop in the current study was reduced by $1.6 \%$ to $29.4 \%$ with the use of net covers.

\subsection{Effects of Agronet Covers on Cabbage Leaf Stomatal Conductance and Chlorophyll Content}

Growing cabbage under net covers enhanced leaf stomatal conductance and chlorophyll content compared to growing the crop in the open field. These findings are consistent with those of Smith (2007) who reported increased stomatal conductance in blushed apple cultivars under netting. At all stages of the crop, agronet covered treatments in the current study registered higher relative humidity values than the uncovered plants. According to Bunce (1999), plants are generally known to react to low relative humidity by closing their stomata with a consequent reduction in $\mathrm{CO}_{2}$ uptake and water loss. Stomatal response to atmospheric humidity is further intensified by the effect of high wind speed, which reduces the leaf water potential by depleting the moist boundary layer close to the leaf surface. The low stomatal conductance observed in cabbage plants produced in the open field in the current study could therefore have been a reaction of the plants to low relative humidity and higher wind levels. Microclimate data from the current study also revealed reduced soil moisture content levels in the open treatments compared to the agronet-covered treatments. Soil moisture reduction leads to a decline in gaseous exchange and leaf water potential (Gitlin et al., 2006; Otieno et al., 2002). 
Although the use of agronet covers generally increased stomatal conductance in the current study, using the 0.9 $\mathrm{mm}$ agronet covers resulted in higher stomatal conductance than the $0.4 \mathrm{~mm}$ netting. Stomatal conductance is known to be affected by factors such as carbon dioxide $\left(\mathrm{CO}_{2}\right)$ concentration, light, humidity and temperature. The differences in stomatal conductance following the use of the different agronet mesh sizes and/or net management regimes could be attributed to the differences in these factors. Elevated levels of $\mathrm{CO}_{2}$ could have resulted under net covers due to resistance to air movement, with the finer mesh imposing greater resistance. This coupled with low light and high relative humidity and temperature affect stomatal conductance. Similarly, a study by Bunce (1999) revealed that stomatal conductance decreases more rapidly in elevated levels of $\mathrm{CO}_{2}$, low light, high relative humidity and high temperature.

Higher values of chlorophyll content estimates were also observed under agronet covers than under open field produced cabbage at all growth stages of the crop. As discussed earlier, agronet covered treatments had reduced levels of irradiance; with the decrease being higher under the finer mesh $(0.4 \mathrm{~mm})$ and the permanently covered treatments than under the larger mesh $(0.9 \mathrm{~mm})$ or where nets were opened thrice weekly. Leaves of shaded plants are thinner and contain larger pigment-rich chloroplasts. Low irradiance causes chloroplasts to be oriented along the upper and lower cell walls in order to maximize light absorption. However, when plants are grown under high irradiance, the chloroplasts orient themselves mainly along the vertical cell walls parallel to incident irradiance (Brugnoli \& Bjorkman, 1992; Park et al., 1996). The higher chlorophyll estimates recorded for the agronet covered treatments in the current study could therefore have resulted from the alignment of the chloroplasts along the upper and lower cell walls as a coping mechanism for the plant following the reduced irradiance levels received under these treatments.

Cabbage covered with agronets also had high tissue water content compared to the control plants in this study. High leaf water content is vital in maintaining maximum amount of chlorophyll in the plant. Water is very important in the synthesis of chlorophyll. High and stable water supply increases the amount of chlorophyll while erratic and low water supply decreases chlorophyll content (Bohrani \& Habili, 1992). In the current study, leaf chlorophyll content also tended to be lower under the finer mesh, which was characterized by high air temperature and soil moisture. Khayatnezhad et al. (2011) observed that very high soil water levels cause a decrease in the chlorophyll content of leaves. Gazula et al. (2005) also detected a decrease in chlorophyll content of lettuce at temperatures above $21{ }^{\circ} \mathrm{C}$ while Lobos et al. (2009) reported increased leaf chlorophyll content in Vaccinium corymbosum as shading intensity under net treatment increased.

\subsection{Effects of Agronets on Yields and Quality of Cabbage}

Cabbage is a cool season crop and as such does not perform well under high temperatures. The optimum temperature range for cabbage production is 15 to $20{ }^{\circ} \mathrm{C}$. Temperatures above $20{ }^{\circ} \mathrm{C}$ delay maturity, increase vegetative growth (number of leaves), and lead to formation of loose heads. In the current study, temperatures remained generally above $20^{\circ} \mathrm{C}$ under the fine mesh $(0.4 \mathrm{~mm})$ agronet covers. Under the larger mesh cover $(0.9$ $\mathrm{mm}$ ), temperatures mostly remained at below $20^{\circ} \mathrm{C}$ but within the upper range of the optimum temperature for cabbage growing. These temperatures could therefore have favoured optimal growth and heading of cabbage, subsequently resulting in the higher yields and better quality heads. Although low temperatures were exhibited by the uncovered treatments, the absence of a netting cover meant that other environmental factors remained unstable resulting in low physiological performance of the crops as evidenced by the low leaf chlorophyll contents and stomatal conductance under these treatments. According to Taub (2010), stomatal conductance decreases in response to low moisture as a result of which the supply of $\mathrm{CO}_{2}$ to chloroplasts reduces. Low physiological performance results in low photosynthetic turnover which in turn reduces growth and subsequently yield. In the current study, microclimate modification under nets resulted in high stomatal conductance and chlorophyll content which could consequently have led to high photosynthetic turnover resulting in the higher yields obtained especially under the $0.9 \mathrm{~mm}$ net.

High tissue water content was also noted for cabbage heads grown under agronet covers than for cabbage heads grown in the open field in the present study. This could have been as a result of high water uptake vis-à-vis reduced transpiration experienced by the net covered cabbage. While low TSS were recorded for cabbage heads grown under agronets compared to those of heads produced in the open field, the study also revealed that temperatures remained consistently lower in the unprotected treatment than in the net covered treatments. Generally low temperatures have been shown to reduce respiration rate and carbohydrate consumption, thus favouring accumulation of soluble solids and vice versa. According to Sivaci (2006), TSS content decreases with increase in temperature, which could explain the differences in TSS among the net covered and unprotected cabbage in the current study. 
Findings from the current study reveal that growing cabbage under the larger $0.9 \mathrm{~mm}$ mesh size agronet results in firmer heads than growing cabbage under the $0.4 \mathrm{~mm}$ agronet cover. Although both treatments had higher levels of tissue water content which plays a major role in tissue turgidity, temperatures remained higher under the $0.4 \mathrm{~mm}$ agronet than the $0.9 \mathrm{~mm}$ agronet. High leaf water potential is a prerequisite for both leaf elongation and expansion and thus for head formation of cabbage. Leaf thickness has also been hypothesized to be closely related to water potential. According to Gardner and Ehling (1965), high temperature lowers the leaf water potential of cabbage thereby reducing leaf thickness, which in turn makes heading more difficult. This results in loose heads and subsequently lower cabbage yields and quality observed under high temperatures. The general increase in yield and quality of cabbage under netting observed in the current study is consistent with findings on pepper where Elad et al. (2007) reported increased yields of two Capsicum annum cultivars when grown under shade nets compared to the no-net control.

The results of this study demonstrate the potential of agronet covers especially those of larger mesh size as a viable strategy for modifying the crop environment and enhancing cabbage physiological performance, yields and quality. Based on the findings of this study, the $0.9 \mathrm{~mm}$ mesh size agronet maintained permanently covered is recommended for use in cabbage crop production in regions with climatic conditions similar to our site. Although opening of nets during the day has been recommended by some authors (Joubert \& Poissonier, 1991), we recommend permanent use of covers under our research conditions since opening of nets would increase labour requirements with no additional benefit in yield and quality. While the findings of this study provide a good foundation for understanding the effects of agronet covers in cabbage production, further testing of these materials using a wider range of mesh sizes and colour, different cabbage varieties and in different cabbage growing agro ecological zones would be beneficial. An evaluation of the effect of different heights of the covers may also be of additional value to the technology. A full economic analysis factoring in the cost of purchase, installation and management of the agronets will also be useful. A comprehensive analysis on the effect of these nets on the sensory attributes, nutritive value and defects would also go along way in promoting the consumption of net grown cabbages.

\section{Acknowledgements}

This is part of Master of Science in Horticulture project by Everlyne Muleke. The study was made possible by the generous support of the American people through the United States Agency for International Development (USAID) under Award No. EPP-A-00-09-00004. The contents are the responsibility of Horticulture CRSP project BioNetAgro investigators and do not necessarily reflect the views of USAID or the United States Government. We wish to acknowledge our project partners, KARI and icipe in Kenya; CIRAD in France, A to Z textiles in Tanzania and University of Abomey Calavi, INRAB, and APPRETEC in Benin for all the support they accorded us in planning and implementation of the project.

\section{References}

Akpo, L. E., Goudiaby, V. A., Grouzis, M., \& Le Houerou, H. N. (2005). Tree shade effects on soils and environmental factors in a savannah of Senegal. Plant Ecol., 131, 241-248. http://dx.doi.org/10.1023/A:1009762123397

Allemann, L., \& Young, B. W. (2008). Vegetable production in Kwazulu Natal. KwaZulu-Natal Department of Agriculture and Environmental Affairs. Resource Centre, Directorate Agricultural Information Services, Pretoria 0001, South Africa.

Bohrani, M., \& Habili, N. (1992). Physiology of plants and their cells. Translation. Chamran University publication.

Brugnoli, E., \& Björkman, O. (1992). Chloroplast movement in leaves: influence on chlorophyll fluorescence and measurements of light-induced absorbance changes related to $\Delta \mathrm{pH}$ and zeaxanthin formation. Photosynth. Res., 32, 23-35. http://dx.doi.org/10.1007/BF00028795

Bunce, J. A. (1999). Leaf and root control of stomatal closure during drying in soybean. Physiol. Plant., 106, 190-195. http://dx.doi.org/10.1034/j.1399-3054.1999.106207.x

Cícero, A., Leite, M., Fagnani, Â., \& Oliveira da Silva, I. J. (2012). Comparison between Thermal Reflect Net and Black Net in Mini-Roses Crop in Holambra- Sp, Brazil. Retrieved from http://www.polysack.com/files/dbdd59e54dd3f85c6b3fb7bd259bd270.pdf

Egerton Metrological Station. (2009). Department of Agricultural Engineering, Egerton University, Kenya.

Elad, Y., Messika, Y., Brand, M., David, D. R., \& Sztejnberg, A. (2007). Effect of colored shade nets on pepper 
powdery mildew (Leveillula taurica). Phytoparasitica, 35, 285-299. http://dx.doi.org/10.1007/BF02981163

FAO. (2009). Cabbage. Food and Agricultural Organization Statistics Quarterly Bulletin of Statistics, 46, 160-165.

Gardner, W. R., \& Ehling, C. F. (1965). Physical aspects of the internal water relations of plant leaves. Plant Physiol., 40, 705-710. http://dx.doi.org/10.1104/pp.40.4.705

Gazula, A., Mathew, D., Streater, J., \& Miller, R. (2005). Temperature and cultivar effects on anthocyanin and chlorophyll b concentrations in three related Lollo rosso lettuce cultivars. HortScience, 40(6), 1731-1733.

Gitlin, A. R., Sthultz, C. M., Bowker, M. A., Stump, S. A, Paxton, C. A., Kennedy, K., ... Whitham, T. G. (2006). Mortality gradients within and among dominant plant populations as barometers of ecosystem change during extreme drought events. Conserv. Biol., 20, 1477-1486. http://dx.doi.org/10.1111/j.1523-1739.2006.00424.x

Horticultural Crop Production Report. (2008). Horticultural Corporation Development Authority (HCDA) validated report. p. 13.

Iglesias, I., \& Alegre, S. (2006). The effect of anti-hail nets on fruit production, radiation, temperature, quality and profitability of 'Mondial Gala' apples. Journal of Applied Horticulture, 8, 91-100.

Joubert, G., \& Poissonier, J. (1991). Yield and growth of tomatoes produced under nets. Infos- Pari., 69, 37-42.

Khayatnezhad, M., Gholamin, R., Jamaati-e-Somarin, S. H, \& Zabihie-Mahmoodabad, R. (2011). The leaf chlorophyll content and stress resistance relationship considering in Corn cultivars (Zea mays). Adv. Environ. Biol., 5(1), 118-122.

Levasseur, V., Pasquini, M. W., Kouamé, C., \& Temple, L. (2006). A Review of Urban and Peri-Urban Vegetable Production in West Africa. XXVII International Horticultural Congress - IHC2006: International Symposium on Horticultural Plants in Urban and Peri-Urban Life.

Lloyd, A. E., Hamacek, A. P., George, R. J., \& Waite, G. (2005). Evaluation of exclusion netting for insect pest control and fruit quality enhancement in tree crops. Acta Hort, 694, 253-258.

Lobos, G. A., Retamales, J. B., del Pozo, A., Hancock, J. F., \& Flore, J. A. (2009). Physiological response of Vaccinium corybosum 'Elliot' to shading nets in Michigan". Acta Hort, 810, 465-470.

Majumdar, A. (2010). Results from the 2009 Insect Monitoring Pilot Project in Alabama. American Vegetable Grower R. Gordon (Ed.). Miester Media, MI. USA. p. 342.

Muleke, E. M., Saidi, M., Itulya, F. M., Martin, T., \& Ngouajio, M. (2013). The assessment of the use of ecofriendly nets to ensure sustainable cabbage seedling production in Africa. Agronomy, 3, 1-12. http://dx.doi.org/10.3390/agronomy3010001

Otieno, O., Asaba, L., \& Kindness, H. M. (2002). Factors affecting uptake and adoption of outputs of crop protection research in peri-urban vegetable systems in Kenya (pp. 27-34). In Sustaining change: proceedings of a workshop on the factors affecting uptake and adoption of Crop Protection Programme (CPP) research outputs held from $10^{\text {th }}$ to $11^{\text {th }}$ May. Department for International Development (DFID), Nairobi, Kenya.

Park Y. I., Chow, W. S., \& Anderson, J. M. (1996). Chloroplast movement in the shade plantTradescantia albiflora helps protect photosystem II against light stress. Plant Physiol., 111, 867-87.

Pérez, M., Plaza, B. M., Jiménez, S., Lao, M. T., Barbero, J., \& Bosch, J. L. (2006). The radiation spectrum through ornamental net houses and its impact on the climate generated. Acta Hort., 719, 631-636.

Retamales, J. B., Montecino, J. M., Lobos, G. A., \& Rojas, L. A. (2008). Colored shading nets increase yields and profitability of high bush blueberries. Acta Hort., 770, 193-197.

Sivaci, A. (2006). Seasonal changes of total carbohydrate contents in three varieties of apple (Malus sylvestris Miller) stem cuttings, Scientia Hort., 109, 234-237. http://dx.doi.org/10.1016/j.scienta.2006.04.012

Smith, A. (2007). Apple tree and fruit responses to shade netting. MSc Dissertation. University of Stellenbosch, South Africa.

Solomakhin, A., \& Blanke, M. (2009). The microclimate under coloured hailnets affects leaf and fruit temperature, leaf anatomy, vegetative and reproductive growth as well as fruit colouration in apple. Annuals of Applied Biology, 156, 121-136. http://dx.doi.org/10.1111/j.1744-7348.2009.00372.x 
Stamps, R. H. (1994). Evapotranspiration and nitrogen leaching during leatherleaf fern production in shadehouses. SJRWMD Spec. Publ. SJ94-SP10. St. Johns River Water Management District, Palatka, F).

Tanny, J., Shabtai, C., \& Meir, T. (2003). Screenhouse Microclimate and Ventilation: an Experimental Study, Institute of Soil, Water and Environmental Sciences, Agricultural Research Organization, UK. p. 129.

Taub, D. (2010). Effects of rising atmospheric concentrations of carbon dioxide on plants. Nature Education Knowledge, $3(10), \quad 21 \quad$ Retrieved from http://www.nature.com/scitable/knowledge/library/effects-of-rising-atmospheric-concentrations-of-carbon-1 3254108

Wambani, H., Nyambati, E. Kamidi, M., \& Mulati, J. (2007). Participatory evaluation of cabbage varieties as a source of food and income for smallholder farmers in north western Kenya (pp. 355-357). African Crop Science Conference Proceedings held from $9^{\text {th }}$ to $15^{\text {th }}$ August, Nairobi, Kenya.

\section{Copyrights}

Copyright for this article is retained by the author(s), with first publication rights granted to the journal.

This is an open-access article distributed under the terms and conditions of the Creative Commons Attribution license (http://creativecommons.org/licenses/by/3.0/). 